for the banana industry. Rice production is being developed. In British Guiana a series of drainage schemes are starting which it is hoped will revolutionize rice growing. The most important thing, however, is to attack illiteracy. The growing political consciousness of the Colonial peoples must be developed on sound lines, but the diversity of conditions in the Colonies makes a standardized approach inapplicable. Continuous association of Colonial peoples with their own welfare and development, and cooperation of all concerned, from the highest to the humblest official, in this endeavour, are the methods to be used. Sir Edward Grigg's amendment was then withdrawn.

\section{International Copyright}

Mr. G. Wren Howard and Mr. Stanley Unwin, both of whom are past presidents of the Publishers Association of Great Britain, have issued a statement raising the thorny issue of international copyright. They point out that the last International Copyright Convention, signed at Berne in 1908, afforded a very considerable degree of protection to the literary and artistic property belonging to the nationals of those countries which signed it. The position to-day, however, is that, of the major active members of the United Nations, the British Empire alone is adherent to the Berne Convention. While Germany, Italy and Japan signed it, the United States of America, the U.S.S.R., and the Chinese Republic did not do so. For practical purposes, almost complete protection is enjoyed by the literary property of United States citizens throughout the British Empire, but it is difficult, owing to the conditions imposed, for British subjects to obtain copyright for their property in the United States. Again, while a translation from the Russian into English is copyright in Great Britain and throughout the Empire, no copyright is afforded to any British literary material by the U.S.S.R.; in China, a considerable trade in material reproduced by photographic process has grown up. It is therefore urged that steps should be taken forthwith, as a part of the plans for reconstruction which are under discussion, to introduce a system of international copyright as soon as world conditions permit.

\section{Exhibition of Newton's Books}

As exhibition of books connected with Newton is being held in the Wigan Central Library from November 23 until early in 1943, to celebrate the tercentenary of the birth of Sir Isaac Newton, at Woolsthorpe, Lincolnshire, on Christmas Day 1642. The exhibition was conceived and organized by the borough librarian, Mr. Arthur J. Hawkes. He has managed to bring together from the resources of the Wigan Library, supplemented by a few books on loan, a most interesting collection of early works on science. It includes copies of most of Newton's published scientific papers and books, together with about one hundred works of earlier and contemporary authors bearing on Newton's discoveries. The original issues of the Philosophical Transactions of the Royal Society in the possession of the Wigan Library are exhibited, together with the first editions of Newton's "Opticks" (1704), loaned by Messrs. Bernard Quaritch, Ltd., and the " $\mathrm{De}$ Revolutionibus Orbium Coelestium" by Copernicus (1543), loaned by the Earl of Crawford. Messrs. Sotheran, Ltd., have loaned the copy of Isaac Barrow's edition of Euclid which was used by Newton as a student at Trinity
College and bears many annotations in Newton's handwriting. All the books exhibited carry lengthy notes attached to them explaining their interest and significance in connexion with Newton.

The exhibition was opened on November 23 by Mr. Leonard Stanley Newton, who is a descendant of the Woolsthorpe family. Wigan is to be congratulated on not letting pass, in war-time, the occasion to celebrate the three hundredth birthday of Newton by the exhibition of "so many and valuable philosophical truths as were never yet discovered and put beyond dispute by the capacity and industry of any one man whatever".

\section{Ministry of Health: Medical Advisory Committee}

The Parliamentary Secretary to the Ministry of Health stated in the House of Commons on November 28 that a Medical Advisory Committee has been set up to advise the Minister on the medical aspects of problems relating to the health of the people. The members of the Committee are :

The presidents of the Royal College of Physicians, the Royal College of Surgeons, and the Royal College of Obstetricians and Gynaecologists ; the chajrman of Council of the British Medical Association; Dr. G. C. Anderson; Dr. J. C. Arthur; Miss A. Bloomfield ; Dr. J. A. Brown ; Dr. E. Rock Carling ; Dr. J. A. Charles; Prof. H. Cohen; Dr. W. Allen Daley; Lord Dawson of Penn; Dr. E. A. Gregg ; Lord Horder ; Sir Wilson Jameson (vice-chairman); Dr. W. S. Macdonald; Dr. A. A. Moncrieff ; Prof. R. M. F. Picken ; Prof. H. Platt ; Dr. A. T. Rogers; Dr. D. O. Twining; Dr. O. Williams; and Miss A. L. Winner.

\section{Imperial Institute of Entomology}

SIR GUY Marshall retired recently from the post of Director of the Institute and has been succeeded by Dr. S. A. Neave. The work of the Institute is well known. It publishes the Review of Applied Entomology and the Bulletin of Entomological Research, identifies insects submitted by entomologists from all parts of the world, distributes collections of named insects, provides initial stocks of parasites of economic importance, and acts generally in an advisory capacity and as a clearing house for matters connected with applied entomology throughout the Empire. A vacancy on the staff has just been filled, but there will be two others within the reasonably near future, and suitable candidates for these posts are now being sought. Further information can be obtained from the Secretary, Imperial Agricultural Bureaux, 2 Queen Anne's Gate Buildings, London, S.W.1, and applications made by May 1 .

\section{Bicentenary of Nicolas Leblanc}

Among the world's benefactors whose discoveries have been ill-requited by their fellows was the French surgeon and chemist, Nicolas Leblanc, who was born at Ivry-de-Pré in the Département of Cher on Decem. ber 6,1742 . Though of poor middle-class parents, he was able to study medicine at the College de France and ultimately became surgeon to the unfortunate Louis-Philippe-Joseph, Duke of Orleans. In 1775 the Paris Academy of Sciences offered a prize of 2,400 livres for a practical process of producing soda from common salt. By 1787 Leblanc had solved the problem, and through the generosity of the Duke was enabled, with Dizé, to erect a factory at St. Denis, and in 1791 a patent was granted him. In 